\title{
AgEIng, Funded PENSIONS AND THE DUTCH ECONOMY
}

\author{
A. LANS BOVENBERG \\ THIJS KNAAP
}

CESIFO WORKING PAPER No. 1403

CATEgory 1: Public FinANCE

FEBRUARY 2005

\footnotetext{
An electronic version of the paper may be downloaded

- from the SSRN website:

www.SSRN.com

- from the CESifo website:

www.CESifo.de
} 


\title{
Ageing, Funded Pensions AND THE DUTCH ECONOMY
}

\begin{abstract}
This paper attempts to paint a coherent picture of the effects of ageing on a small, open, economy with large pension funds in different institutional settings. Quantitative scenarios are projected with an applied computable general equilibrium model with institutional details. We find that ageing leads to a tighter labor market, increasing costs for both pension funds and the government, and leaving the economy vulnerable to financial and further demographic shocks. We show that defined benefit pension arrangements can be destabilizing, but less so if an average-wage variable-indexation contract is chosen. Government can help by adopting a policy of tax smoothing, but the single most important determinant of the net burden of ageing is the eventual size of the increase in labor market participation of older workers. The intergenerational welfare effects of demographic shocks and changes in international interest rates are sizable and should be an integral part of the assessment of different policy instruments.
\end{abstract}

JEL Code: E17, H30, J18

Keywords: ageing, funded pensions, applied general equilibrium models, the Netherlands.

\author{
A. Lans Bovenberg \\ Department of Economics \\ Tilburg University \\ P.O. Box 90153 \\ 5000 LE Tilburg \\ The Netherlands \\ a.l.bovenberg@uvt.nl
}

\author{
Thijs Knaap \\ Utrecht School of Economics \\ Utrecht University \\ Vredenburg 138 \\ 3511 BG Utrecht \\ The Netherlands \\ t.knaap@econ.uu.nl
}

This paper is based on a research project commissioned by the Dutch Ministry of Social Affairs and Employment (SZW) and Pension Research Foundation (SPW) and conducted at Ocfeb, Erasmus University Rotterdam. We thank Leon Bettendorf, Peter Broer, Juan Carlos Conesa and seminar participants at CESIfo Munich for extensive comments; any remaining errors are ours. 


\section{Introduction}

\section{Ageing, pensions and the economy}

The pension system in the Netherlands consists of three pillars: a government-run pay-as-yougo system, funded compulsory occupational pension schemes and voluntary private savings. The size of the second pillar, funded pensions, is considerable: in the year 2000 the funds had accumulated around $100 \%$ of GDP in assets. For many people, the accumulated rights on these funds constitute an important part of their retirement provions.

In the coming decades, the Dutch population will age due to the combined effects of a lower birth rate, a lower mortality rate and the baby boom that followed World War II. These developments, together with the maturing of their membership, will severely reduce the premium base of occupational pension funds compared to their future obligations. The ratio between obligations and the premium base is about six today, but will rise in the coming decades. This makes pension funds more susceptible to risk: adverse shocks on financial markets can no longer be easily absorbed by raising premiums.

At the same time, ageing makes labor relatively scarcer than capital. This is bad news for maturing pension funds, who have their obligations coupled to the wage rate, but depend on the rate of return on capital for their income. As capital income declines, their obligations rise. A compounding problem is that the increasing demand for nontraded goods and services (such as care for the elderly) caused by ageing will squeeze the labor market, leading to additional wage inflation.

Finally, several European countries seem ill prepared for the ageing problem. It is feared that ageing will saddle these countries with considerable financial and budgetary problems. This can cause an inflationary spiral that degrades the value of European firms, with adverse effects on the real return to pension funds' wealth. All these setbacks loom at a time when the pension funds are more vulnerable to risk because of their shrinking premium base. Thus, not only payas-you-go systems but funded systems appear to be vulnerable to ageing. This paper aims to show how large this vulnerability is.

We analyze the macro-economic interdependencies between ageing, risks and pension funds in an applied general equilibrium framework, explicitly taking into account the multiple relationships between the economy and occupational pension funds. The two are linked in several ways: on the one hand, the value of the funds' assets and obligations depends on macroeconomic developments on the Dutch labor market and the international financial markets. On the other hand, the level of pension premiums and benefits affects the labor market, the capital market and the goods market. The complicated two-way interaction between pension funds and the rest of the economy has important consequences involving for instance the distribution of income between active and retired generations.

\section{Structure of the paper}

We proceed as follows. After a short introduction to our model, we describe the benchmark scenario. We then explore different ways to deal with the financial burdens of ageing. We discuss policy options for pension funds as well as the government, the latter being in charge of the pay-as-you-go (PAYG) system. 
Both parties—-pension funds and government—start off in a state of disequilibrium. With expected financial returns as they are and the current level of premiums, pension funds cannot finance future pensions that are fully indexed to gross wages. Raising premiums or reducing indexation are alternative ways of addressing this problem. We investigate the implications of these alternatives for a number of macroeconomic variables (including wages, employment and gross production) and for the standard of living for current and future generations.

The current levels of taxation are also insufficient to cover the future fiscal costs of ageing. The rising net PAYG benefits, tied at present to net market wages, will force the goverment to pick up an increasing part of the PAYG bill through general taxation. This will cause either tax rates or the national debt to rise. We analyze the macroeconomic implications and intergenerational distribution issues, and study a number of policy options: smoothing tax rates by cutting public debt, stimulating labor participation and importing labor from abroad.

To explore the vulnerability of the Dutch pension funds and the national economy, we proceed by analysing the effects of an adverse shock to the rate of return on capital. Lower rates of return may be caused by either world wide ageing or imported inflation from European countries suffering from fiscal imbalances.

Finally, we analyze how these results are affected if the tradability of goods and services declines. With the pension funds sustaining national consumption when the number of pensioners rises, prices of nontradeables increase, causing wage inflation and therefore higher (defined benefit-) pension obligations for occupational pension funds.

The purpose of the paper is twofold: firstly, it aims to show the different channels through which ageing and pensions impact the economy, how these effects propagate, what the feedback effects are, and how the income distribution across and within generations is affected. Secondly, it aims to quantify these effects through numerical simulations, thereby allowing one to assess the relative importance of these different channels.

\section{The IMAGE model}

The interactions between ageing, pension funds and the Dutch economy are studied using the IMAGE model. This dynamic overlapping generations-model is documented in Broer (1999). The analysis is conducted in the tradition of Auerbach and Kotlikoff (1987), and can be compared to Kotlikoff et al. (2001), Börsch-Supan et al. (2003) and Beetsma et al. (2003), among others. It differs from these approaches in a number of ways: we concentrate on ageing in a small, open economy, which does not affect returns on international financial markets. Furthermore, we focus on the funded defined-benefit pension system and the ways in which policy choices in that system interact with the economy. Even though it is a part of our model, we do not analyze alternative policy choices in the PAYG pension system, as this has already been the subject of much analysis in the international literature. This section introduces the model without trying to be exhaustive-most mathematical detail is left out, for instance. For a complete overview of the model, we refer the reader to the documentation on our website (see http://image.ocfeb.nl.) However, Table 1 presents the key parameters and appendix A gives some background on the optimization problems: the problem for households is discussed in A.1 and that for firms in A.2. 
Table 1: Some key parameters

\begin{tabular}{|c|c|c|}
\hline$\alpha$ & 0.02 & labour saving technical progress \\
\hline$\beta$ & 0.02 & rate of time preference \\
\hline$r$ & 0.04 & real rate of interest \\
\hline$\gamma$ & 0.25 & intertemporal elasticity of substitution \\
\hline$\eta_{H}$ & 0.25 & elasticity of productivity in the time preference of households \\
\hline$\sigma_{u}$ & 0.56 & $\begin{array}{l}\text { intratemporal elasticity of substitution between consumption of goods } \\
\text { and the leisure-care composite }\end{array}$ \\
\hline$\sigma_{v}$ & 0.65 & intratemporal elasticity of substitution between leisure and health care \\
\hline$\sigma_{y}$ & 0.5 & $\begin{array}{l}\text { elasticity of substitution between raw materials and value added in the } \\
\text { tradable goods sector }\end{array}$ \\
\hline$\sigma_{H}$ & 0.5 & $\begin{array}{l}\text { elasticity of substitution between labour and capital in the tradable } \\
\text { goods sector }\end{array}$ \\
\hline$\delta$ & 0.115 & technical depreciation of capital \\
\hline$\epsilon$ & 0.281 & $\begin{array}{l}\text { net replacement rate of PAYG pension as a fraction of the average wage } \\
\text { rate }\end{array}$ \\
\hline$\phi_{0}$ & 0.7 & total pensions as a fraction of the final wage at full pension build-up \\
\hline
\end{tabular}

In the IMAGE model, 560 types of households are active every period (the standard period is one year): there are 80 cohorts, and each cohort features 7 types of workers, differing in exogenous productivity. These types thus represent different income-groups in the economy. Each household consistently maximizes lifetime utility, using labor-leisure allocation and consumption as its instruments. The mathematical structure of the household problem is the subject of appendix A.1 on page 16. Firms maximize their value, defined as the present value of the stream of dividends. From this follow the optimal labor and investment demands. The model is based on recent data and incorporates the institutions of the Dutch economy that are most affected by ageing: the government, the health sector and the pension funds. We assume a competitive labor market, so that wages are equated among the three production sectors: the government, the health care sector and the rest of the private sector. Their size can be read from Table 2 .

Table 2: Some key variables

\begin{tabular}{lr}
\hline Employment volume per sector $(1000$ man-years) \\
Government (with education) & 728 \\
Health care & 661 \\
Firms & 4963 \\
& \\
Wealth (\% GDP 99) & \\
Government debt & $55.6 \%$ \\
Pension funds assets & $97.7 \%$ \\
\hline
\end{tabular}

The government levies (proportional) taxes on consumption, and labor- and capital income. That money is spent on government consumption, interest payments, subsidies and lump-sum transfers. Public consumption is a fixed fraction of GDP; public subsidies go to public health insurance, which is reimbursed a fixed fraction of its expenditures, and to the PAYG pensions, 
to the extent that the exogenously fixed premiums do not cover the costs. Age-specific transfers are tied to the gross wage rate. The government aims to maintain a constant public debt-GDP ratio and uses the income tax rate to close its budget. Its initial debt rate is about 56\% (Table 2).

The two mandatory pension systems are a PAYG scheme, which pays out a uniform basic minimum pension after age 65 that is tied to the wage rate, and a funded occupational pension scheme that provides benefits to top up the basic public pensions. Dutch occupational pension funds are large: in 1999, their combined assets were almost equal to the nation's GDP. Pension funds are capital-based and receive premiums out of working-age persons' wages.

The premium is levied on that part of the wage that exceeds the so-called franchise, and payment confers to the participant the right to a defined-benefit pension. Pensions are based on the last-earned wage, are tied to the level of gross wages in the economy. Their level depends on the accrued rights of the worker. The fund earns the international interest rate; discrepancies between its assets and the present value of its obligations are covered by adjusting the premium at a specified pace. Contributions to the pension fund are deductible from taxable income while the benefits later in life are taxed. In the PAYG scheme the contribution rate is fixed and shortages are covered by the state.

There are two types of health insurance, private and public, for agents on either side of a statutory income ceiling. Below the ceiling, agents have mandatory insurance through public health insurances. The public insurance scheme reimburses in full, with help of the state. Public health insurance fixes its premiums, which are proportional to income, so that its budget is balanced each year. Privately insured households, in contrast, pay a lump sum contribution. The private health insurance sector transfers some of its premium income to the public insurance system to compensate that sector for the bad health risks of low-income households. Special medical treatments, which are difficult to insure on the private insurance market, are covered by a special insurance sector (AWBZ) to which both publicly and privately insured households contribute. Health expenditures, finally, require complementary time allocation from the consumers.

The model abstracts from a number of institutions, including several early-retirement schemes. Agents are endowed with perfect foresight, so that risks do not figure in our calculations. We do not model differences between men and women, and abstract from bequests using a Yaari (1965) cohort-level inverted life-insurance. The absence of bequests may lead to an overestimation of the intergenerational effects of shocks, as bequests typically help smooth those effects across generations. Pension funds are homogenous and represented by a single, representative fund. Markets, including the labor market, clear every period ruling out unemployment. We abstract from business cycle considerations to focus on the long-term effects of demographic trends. Our model, with its assumption of perfect foresight and intertemporal maximization by agents, produces a benchmark scenario that can be used for policy analysis concerning long-run issues.

While wages are determined nationally, the return to capital is determined on international financial markets. We assume a constant real rate of return of $4 \%$ but also explore a case in which the rate of return declines. 


\section{The benchmark path}

In the benchmark scenario, the starting point of our simulations, the assets of pension funds are not large enough to cover the obligations to current and future retirees (including an indexation of benefits to wages) and premiums are below their long-run level. This scenario is an attempt to approximate the current situation, even though much of the model is calibrated to 1999 data. The lack of funds in 1999, which was not actually observed in that year, can be explained as follows: first of all, we assume an average real return to capital of $4 \%$, which are lower than the returns that were anticipated in 1999. Secondly, the financial markets had not yet reached their top in 1999.

\section{Variable premiums}

On the base path, funds use their premiums, the percentage of income above that franchise that is paid to into the pension fund, as an instrument to cover the shortage in assets. The premium responds to the coverage rate (assets as a ratio of current pension obligations), which is targeted at 1.05. The low premium rate in the base year, combined with the smaller-than-desired coverage rate, leads to a sharp increase in premiums in the base year. We have constrained the premiums to a maximum of $25 \%$, with a maximum yearly increase of 2 percentage-points.

The effects of ageing for the cost level of pension funds and government can be seen from figure 1. The income tax rate increases when the dependency ratio goes up, and reaches its highest level in 2040. Rising costs of the PAYG scheme play an important rol in this increase. After an initial increase, occupational pension premiums stabilize at their long run level around $16 \%$.

Figure 2 gives the gross wages (corrected for $2 \%$ technological growth). Wage costs peak around the time when the labor market is tight due to ageing. Net wages ${ }^{1}$ are in the same figure. These (also corrected for technological growth) are under pressure in the next decades due to rising tax rates and, initially, higher pension premiums. Higher tax rates also affect the net (funded) pensions in the same figure. However, as pensioners do not pay pension premiums the decrease in net pensions is smaller compared to that in net wages.

Higher costs of labor reduce the demand for labor, while lower net wages depress labor supply. Together with demographic developments, this results in falling employment until 2030 (see figure 3). Gross domestic product (corrected for technological growth) reflects the downturn in employment.

Pension funds face two problems on the benchmark path: a low coverage ratio and a low initial premium. The tight labor market exacerbates these troubles because the resulting inflationary pressure on gross wages increases pension fund obligations. Despite the tighter labor markets, net wages decline compared to net pensions due to higher occupational pension premiums.

\footnotetext{
${ }^{1}$ Net wages refers to the payment that the worker receives after taxes, employer-paid premiums and the pension fund premiums.
} 


\section{Policy instruments for pension funds}

In the base case, the financial problems of occupational pension funds are shifted to active workers. To protect the purchasing power of workers compared to that of the retired population, funds can opt for alternative instruments to address their financial problems. We discuss a number of alternative measures, which are rather extreme but are intended to delineate the borders of the playing field for pension funds. In the end, pension funds probably will opt for a combination of measures. The measures involve suspending benefit indexation and eliminating the final-wage system in favor of a system based on average wages.

\section{Fixed premium, variable indexation}

In our first alternative simulation, we let the pension premium increase to its long run level of $16 \%$ straight away (figure 4). This means that the fund's financial troubles are no longer borne by the working population. Instead, current retirees carry the burden of the initial disequilibrium because their pensions are no longer indexed to gross wages as long as the fund's assets are too low (figure 5). (We allow lower indexation up to $-4 \%$; this level of indexation corresponds to nominal freezing of the pensions, with $2 \%$ inflation and $2 \%$ technological growth). Under this rule, additional indexation is possible if the coverage ratio exceeds 1.05. This way, pensioners share in both positive and negative shocks.

Pensions lag behind gross wages about 1\% each year during the first decade. Figure 6 shows the effects of reducing indexation for the net pensions. Reducing indexation leads to temporarily lower pensions, where net pensions lag behind the purchase power development of active workers for two decades. The effect fades after the generations whose pensions have been cut are no longer present. Generations that start retirement in 2020 or later profit from increased indexation (see figure 5) and a relatively high final wage, caused by the tight labor market in 2020 (figure 2). This explains why net pensions grow faster than net wages between 2020 and 2040 (see figure 6). The use of the indexation instrument instead of the premium instrument eases the costs on labor and protects net wages in the early years. This boosts total employment (figure 7).

The welfare effects ${ }^{2}$ on different generations are in figure 8 . The year of birth of the different generations is on the horizontal axis. Generations that have just retired when indexation is reduced lose the most. Their benefits from funded pensions make up the largest part of their income, as opposed to older generations who rely more on the first (PAYG-) pillar. Generations born between 1960 and 1990 do not retire until after the indexation is no longer reduced. They gain relative to the base path because of their lower pension premiums.

\section{Average-wage pensions}

Another policy option for pension funds is the use of average-wage pensions instead of finalwage pensions. Under the former system, pensions are based on the average wage earned over

\footnotetext{
${ }^{2}$ Welfare effects are a percentage of remaining lifetime utility, compared to the base path. Welfare is generated by consumption as well as leisure. The welfare effect in figure 8 is the average effect on seven different income groups. We will report average effects only if their pattern between income groups is sufficiently similar.
} 
the worker's entire career, albeit indexed to the sector-wide wage level to correct for inflation and the standard of living. The switch takes place, unexpectedly, in the base year.

There is a transitory regime: for workers who had already entered into the final-wage system, the average wage until the base year is set to their current wage. From then on, the indexation of their rights follows the sector's average wage instead of their individual wage path.

The accumulation rate of pension rights is increased in this plan, so that the expected final pension is equal to that in the final-wage scheme. Nevertheless, the shift to an average-wage system shows a lower level of initial premiums (if premiums are the fund's instrument) due to the fact that most of the baby-boom generations are still in the middle of their career when the switch is made-compare figure 9 to figure 1 . This makes the final-wage system expensive, as many members of this generation enjoy a consideable backservice over their accumulated rights. The premiums under the average-wage system are more stable, because they are not influenced by these fluctuating backservice-obligations.

The average-wage system increases the net wages with respect to the base path (see figure 10), which contributes to an increase in the supply of labor (figure 11). The higher net wages reflect the inital lower costs of the system. Pension benefits initially increase under the average-wage system because older employees whose wage profiles are over the peak, actually profit from the introduction of the average-wage system and its terms of transition (figure 10). Their current rights are protected by the terms, while they can increase their future rights using the new, higher, rate of contribution. On top of that, the fact that their final wage is lower than their current wage no longer affects the value of their pensions.

The opposite holds for younger generations, who have not yet made their careers. ${ }^{3}$ Their pension benefits are lower because the backservice on their previous contributions no longer exists. The higher rate of accumulation, which works to improve their benefits, is not enough to overcome this loss. However, these lower benefits do lead to an increase in labor supply, caused by the young generation's desire to increase their saving for retirement.

The welfare effects of a switch to average-wage pensions show differences not only between generations, but also between different income groups. Figure 12 shows the effects for three groups in current and future generations. The low incomes correspond to $10 \%$ lowest incomes in a cohort, the high incomes are the top $5 \%$ of a generation. The latter lose when the switch to an average-wage system is made, because their wage profile goes up the most in their final active years, giving them a generous backservice under the final wage system. The lower and middle incomes profit from the new system. The gains for lower incomes are relatively modest as their involvement in the funded-pension system is small. Figure 12 further shows that the cohorts in the middle and lower incomes that profit the most are those that are just before retirement. As indicated above, these cohorts have little career (and hence, backservice) left but do profit from the higher accumulation rate. Note, finally, that the effects on national income and labor supply are relatively modest compared to the changes in the income distribution.

Average-wage pensions with conditional indexation

A major advantage of the average-wage system over the final-wage system is the increased

\footnotetext{
${ }^{3}$ These perverse aspects of our, admittedly simple, transition rule can easily be mitigated in practice, for instance by making the accumulation rate dependent on the age of the participant.
} 
power of the indexation instrument. Under this system, reducing the indexation of existing rights is possible not just for the rights of current retirees, but also for those who are still in the current labor force, whose claims are indexed with the growth of wages in the economy. The increased effectiveness of the indexation instrument is illustrated by the following case, in which we switch off the premium instrument by setting premiums at their long-run level immediately and use only the indexation of current (worker and pensioner-) rights to guide the coverage ratio to its desired value. This is comparable to the simulations in the previous paragraph, in which the indexation instrument was employed exclusively to restore the coverage ratio in the final-wage system. However, we will find that this instrument is much more effective under an average-wage system.

The results of this simulation are in figures 13-17. The first figure shows that the premium has indeed been set at its long-run level. ${ }^{4}$ As the risk surrounding the funded pensions is borne by a much larger number of people, pensioners have to contribute less to pay off the funds' deficit; hence, their incomes remain relatively stable (compare figure 14 to figure 5, taking into account the different scale of the vertical axes).

We compare this switch to an average-wage system, which uses the indexation instrument, to the case in which the switch was accompanied by the exclusive use of the premium instrument. As we might expect, the pension benefits increase less under the current system and net wages and employment go up more than if the premium instrument is used (compare figures 15 and 16 to, respectively, figures 10 and 11).

In conclusion, we note that the use of the indexation instrument alleviates the pain that is associated with the initial underfunding of the pension funds. If the indexation of the rights of active workers is suspended under an average-wage system, the development of pensioners' incomes is more in line with that of workers, compared to the case in which the premium instrument is used (compare figure 15 to figure 10 and figure 2) or to the case in which only the indexation of pensioners' rights is suspended (compare figure 15 to figure 6).

\section{Government policy}

The government has several options at her disposal to help with the problem of ageing. The policy options have consequences for the national budget (including the costs associated with the first pillar-PAYG system) as well as for the pension funds (who manage the second pillar). This paragraph analyzes the macroeconomic links between government policy, pension funds, and intergenerational distribution. We discuss the reduction of government debt by raising taxes to their long-run levels immediately and the encouragement of labor participation.

\section{Constant taxes and premiums}

In the simulations so far, government debt was kept constant as a fraction of national income by adjusting the income tax rate on a yearly basis. Figure 1 shows that this policy implies that those generations, that are active when the ageing of society peaks in 2040, pay relatively high

\footnotetext{
${ }^{4}$ The similarity between the two simulation scenarios can be observed when comparing figure 13 to the comparable figure in the previous exercise, figure 4.
} 
taxes. Several considerations, including the desire to spread the costs of ageing equally across generations and avoid distortions due to fluctuating tax rates, call for constant tax rates over time. The level of this constant rate follows from the condition that the government has to stay solvent. In practice, this means raising rates at the present time to pay off a part of the national debt.

We simulate a scenario in which the government decides to enact this type of policy. The results of the simulation are in figures 18 through 22. The rate of income tax is higher in the initial years of the simulation, but lower in the later years (compare figure 19 to figure 1). In this way, the costs of ageing are in fact brought forward. The national debt (as a percentage of national income) decreases for two decades (figure 18) to stabilize at a level of $35 \%$ of GDP. ${ }^{5}$

Bringing the costs of ageing forward influences labor supply. By keeping the income tax rate constant, the net wage will be lower in the base year but declines much less afterwards. ${ }^{6}$ This stimulates labor supply at precisely the moment that the labor market is tight, due to population ageing. Constant rates of taxation thus help the price mechanism to allocate labor supply to those periods in which labor is most scarce. Ageing, in this scenario, leads to a smaller fluctuation in the costs of labor, in production and in employment (compare figure 20 to figure 2 and figure 21 to figure 3). Not surprisingly, the welfare effects (figure 22) show that reducing the national debt in anticipation of an ageing population taxes the current generations to the benefit of future generations.

In this simulation, health insurance is not counted in the government budget. Those governmentadministered insurance funds change their premiums each year to avoid shortages. An alternative scenario, in which the insurance premiums are kept constant as well, leads to the elimination of government debt in just two decades, after which it increases to about $16 \%$ of GDP.

\section{Ageing and labor participation}

Population ageing reduces the ratio between the number of active and retired members of society. This trend can be offset by increasing labor participation among the active part of the population. Increases in participation are possible, and have occured in the past. During the last decades, for instance, the labor supplied by young women (between 20 and 45 years) has increased markedly due to cultural changes and an increase in the educational attainment of that group. Also, the opportunity to work part-time has made the labor market more accessible for women with children. In the coming two decades, the women who have entered the labor market in recent years will be part of the older half of the labor force (between 45 and 65 years). This part of the labor force, especially that older than 55, has shown a decrease in participation over the last thirty years (though this trend appears to have reversed slightly during the last half of the 90s). How labor force participation of 45-65 year-olds will develop in the future is uncertain, and will depend on cultural developments as well as government policy aimed at stimulating participation of older workers.

\footnotetext{
${ }^{5}$ Recent computations by the CPB Netherlands Bureau for Economic Policy Analyses indicate that sustainable public finance (through constant rates of taxation) requires the government debt to decline to $15 \%$ of GDP in 2030. See CPB (2003b).

${ }^{6}$ The changes in net wage in figure 20 actually lead to a decline in net wage. This is caused by increasing pension premiums in the early years, and by the increasing costs of health insurance in the later years.
} 
Table 3: Participation in three age groups

\begin{tabular}{|c|c|c|c|c|}
\hline \multirow{3}{*}{$\begin{array}{l}\text { year } \\
\text { age group } \\
\text { labor participation }\end{array}$} & \multicolumn{4}{|c|}{2000} \\
\hline & $20-44$ & $45-49$ & $50-54$ & $55-59$ \\
\hline & & & & \\
\hline IMAGE base path & $73.9 \%$ & $68.7 \%$ & $61.5 \%$ & $42.7 \%$ \\
\hline CPB projection & $73.4 \%$ & $70.5 \%$ & $63.5 \%$ & $42.2 \%$ \\
\hline year & \multicolumn{4}{|c|}{2010} \\
\hline age group & $20-44$ & $45-49$ & $50-54$ & $55-59$ \\
\hline \multicolumn{5}{|l|}{ labor participation } \\
\hline IMAGE base path & $70.5 \%$ & $66.8 \%$ & $58.6 \%$ & $38.6 \%$ \\
\hline CPB projection & $75.2 \%$ & $76.6 \%$ & $69.3 \%$ & $49.5 \%$ \\
\hline year & \multicolumn{4}{|c|}{2020} \\
\hline age group & $20-44$ & $45-49$ & $50-54$ & $55-59$ \\
\hline \multicolumn{5}{|l|}{ labor participation } \\
\hline IMAGE base path & $71.5 \%$ & $65.9 \%$ & $57.3 \%$ & $35.7 \%$ \\
\hline CPB projection & $76.3 \%$ & $78.5 \%$ & $74.3 \%$ & $53.9 \%$ \\
\hline
\end{tabular}

CPB Netherlands Bureau for Economic Policy Analyses has developed several long-term scenarios for labor participation. To find out about the sensitivity of our simulations to changes in labor participation, we use an optimistic scenario for labor supply, the European Coordination scenario (see CBS/CPB, 1997). Table 3 compares labor participation on our base path to the development of participation in the CPB-scenario. In our projection, participation drops over time, due to the increase in income tax rates over time (see figure 1). In the projection from the $\mathrm{CPB}$, however, the participation rate goes up; the recent increase in the participation of older employees is continued into the next decade. This trend is explained by cultural changes, that stimulate participation among older women, compared to their participation during earlier cohorts. Cutbacks in early retirement schemes have also been taken into account. This allows us to interpret the CPB's scenario as a policy scenario in which labor participation is encouraged in a number of ways.

We exogenously introduce the increase in labor participation that is stipulated by the CPB scenario. The results of this simulation are in figures 23 through 24 . In it, effective labor supply will increase markedly for the next 15 years, due to the higher participation of older employees. The supply of labor does decrease when the baby boom generation withdraws from the labor market, but the size of the decline is smaller than in previous simulations (see figure 24). The labor market goes through a cycle of relative abundance and relative scarcity. This development is reflected in both the costs of labor (real wage falls until 2010, then peaks at 2030) and the rate of income tax (figure 23). The effects on the net wage of changes in the gross wage are partly negated by the changes in the rate of taxation. Taxes still have to go up in order to cover the costs of population ageing, but the increase is much smaller than in previous simulations. This indicates that the increase in labor participation is good news for the government in more than one way. Firstly, wages increase less because of the increased supply of labor. This causes a decline in the costs of government services, as well as enlarging the different tax bases. Sec- 
ondly, the larger premium base for pension funds allows them to lower the premium compared to the base path (compare figures 23 and 1). The smaller fluctuations in taxation cause the net wage to respond less to demographic developments. Moreover, net wages have declined less than previously estimated because of the somewhat lower pension premiums.

We find that an increase in labor participation is a powerful cure for the problems caused by population ageing. Its effects on the economy are beneficial to growth and employment, while keeping costs low for the government. The initiatives aimed at increasing participation should therefore be welcomed; it is not certain, however, that they will be as effective as the scenario from this paragraph assumes.

\section{Risk analysis: capital market and life expectancy}

This section explores the vulnerability of an ageing economy to risks. We look at the repercussions of a negative shock in the return to capital, and an unexpected increase in life expectancy. Both shocks will cause pension funds to respond, and we discuss different options for their response. This will highlight the impact of the pension contract on the Dutch economy.

Ageing reduces the rate of return to capital...

Ageing OECD countries supply the bulk of capital on world financial markets. The supply of capital will probably increase in the coming years, as the baby boom generations save for their retirement years The demand for capital, in contrast, will be low, because less jobs need to be created for the shrinking labor force. It thus appears that the forces of supply and demand will put downward pressure on the rate of return on capital.

We employ the interest rate projection of the INGENUE model, which is based on a worldwide demographic scenario (Aglietta et al., 2001). The projection is in figure 25, and it confirms the above analysis: the model predicts a declining rate of return for the next two centuries, after which a new equilibrium is found about 50 basis points below the real return of $4 \%$ that we employed in our base projection. This projection accounts for the absorption of savings from the OECD countries by the developing world, where the population is relatively young.

... as do budgetary problems.

Even though most European countries will have to cope, in differing degrees, with an ageing population, not every country is as well prepared to take care of the future costs that this problem will entail. Especially countries in which the provision of pensions is arranged mainly through a pay-as-you-go system face fiscal imbalances. This could result in inflationary pressures as well as a significant increase in taxes, both with negative consequences for the investment climate and the returns that Dutch pension funds can expect on their investment in these countries.

Lower rate of return means a lower coverage rate...

We are interested in the sensitivity of the Dutch economy, and especially the pension funds, to the effects of a lower rate of return. We therefore analyze the effects of the INGENUE-scenario that was introduced above in our own model of the Dutch economy. The fall in the return to capital (together with the increase in wages caused by it) immediately causes a fall in the 
coverage ratio of pension funds. We study the effects of a number of possible responses to this problem, where we use the same set of strategies that we studied in the previous section. In the first two simulations, funds keep the final-wage system in place and deal with the lower rate of return by increasing their premiums (figures 26 through 28) or by cutting the indexation of current pension benefits (figures 29 through 32).

... with higher premiums...

When pension funds use the premium instrument to increase their insufficient coverage ratio, the premiums quickly go up to the maximum level of $25 \%$ (see figure 26). Premiums are fixed at this level for the next 20 years, after which they return to their new steady state level just below $20 \%$. This level exceeds the previous steady-state premium of $16.4 \%$, which is a consequence of the permanently lower rate of return (which is $3.5 \%$ instead of $4 \%$ ).

... or lower benefits.

An alternative course of action for the pension funds is to freeze premiums immediately at their new long-run level of $19.6 \%$ (corresponding to the new steady-state rate of return of $3.5 \%$ ) and cope with the shortages by revoking the indexation of pensioners' benefits. The growth of benefits will, in that case, lag about $4 \%$ behind the growth of wages for eight years. ${ }^{7}$ After this period, indexation of benefits to wages is gradually restored.

\section{Lower rates of return stimulate labor supply}

The lower rate of return required by financial markets serves to increase the level of investments. This is beneficial to labor productivity and leads to higher gross wages. In the long run, employment increases by $0.7 \%$, while GDP grows by $2.5 \%$ (figures 28 en 32). In the case in which the indexation instrument is used, changes in net wages are only small. As it turns out, the higher gross wage rate is just about offset by the higher steady-state pension premium (figure 31). Premiums are increased by a large amount if the premium instrument is used exclusively (figure 26), which causes net wages and labor supply to drop initially (figures 27 and 28). Using the indexation instrument prevents sizable short term effects on net wages and labor supply (compare figures 31 and 32 with figures 27 and 28, respectively) but severely decreases the value of net pensions in the initial years (compare figures 31 and 27).

\section{Welfare effects}

Figure 33 shows the welfare effects of a negative shock in the rate of return for the different cohorts under two different pension fund policies. In both cases, the fall in the rate of return harms the welfare of future generations: their lower income from capital weighs heavier than the (slightly) higher net wage. In the short run, the policy option chosen by pension funds is important. The cohorts that were born around 1980 pay most if the premium instrument is used. Cutting into the indexation of current pensions instead protects this generation, but instead harms the welfare of those born around 1930.

\footnotetext{
${ }^{7}$ That the growth in benefits is $4 \%$ slower than that in wages, is the result of $2 \%$ yearly inflation and $2 \%$ technological growth in wages, when we assume that the funds are able to freeze nominal pension benefits.
} 
To average-wage with premium instrument...

For the second set of simulations, we assume that the fall in the rate of return is followed by a transition to a system in which pension benefits are tied to average wages, rather than final wages. We further assume that the transition takes place under the rules that were discussed in the previous section. In these simulations, we find that in case the premium instrument is used, the path of pension premiums is much smoother than in the final-wage system (compare figures 34 and 26). While net wages remain under pressure for the first twenty years because of higher pension premiums, net pension benefits turn out to be higher than before because of the transitory regime, ${ }^{8}$ as are gross wages (to which these benefits remain indexed).

\section{...or with a more effective indexation instrument.}

The scenarios in which an average-wage system with conditional indexation is introduced all point to the increased effectiveness of the indexation instrument, as current as well as future pension rights can be adjusted in the face of shortages. The broader base for bearing risks ensures that the suspension of benefit indexation only lasts a short while, compared to a finalwage system (compared to figure 30, indexation correction is only at its minimum level for one year). Moreover, net wages and net pension benefits do not diverge as sharply. Higher net wages under the regime of conditional indexation stimulate the supply of labor in both the short and the long run. The welfare effects indicate that the transition to an average-wage system protects the middle- and lower incomes against the effects of a drop in the rate of return. The higher incomes, however, experience a drop in their pension benefits (see figures 37-38).

\section{Nontradeables}

When the baby boom generation retires, the local supply of labor will decrease. This will lead to a decline in Dutch production capacity, while at the same time the assets accumulated by pension funds will provide the means to keep national consumption at its usual level. The money that was saved and turned into foreign investments can then be used to import consumption goods to serve the excess demand.

However, not all goods and services are internationally tradeable and can be imported. A high demand for nontradeables combined with a reduced capacity to produce locally will cause the real exchange rate to appreciate; that is, nontradeables will become more expensive relative to tradeables. This change in relative prices will direct production factors from the tradeable- to the non-tradeable sector, as that is the only way in which the local production of nontradeable goods and services can meet local demand, despite the reduced availability of labor.

The reallocation of scarce labor from the tradeable- to the nontradeable sector, however, will cause a period of stress on the labor market. As sector-specific skills and capital need to be converted, wages will be higher than normal during the transition. This raises the price of nontradeables and harms the competitiveness of the traded-goods sector and boosts the costs of (labor-intensive) government services. Pension funds, who have indexed their benefits to the wage level, also see the value of their obligations rise.

\footnotetext{
${ }^{8}$ As we noted before, it is possible to construct a regime under which the transition to an averagewage system would be less beneficial to the older generations.
} 
We simulate a scenario in which the Dutch market sector is divided into two subsectors, tradeable and non-tradeable. We use the definitions of exposed and sheltered sectors that have been used in the CPB's JADE model (CPB, 2003a). Government and the health sector form a third sector. The employment shares of these sectors are in table 4.

Table 4: The size and production structure of the three sectors

\begin{tabular}{llll} 
Sector & Tradeables & Nontradeables & $\begin{array}{l}\text { Government } \\
\text { health }\end{array}$ \\
\hline $\begin{array}{l}\text { Employment- } \\
\text { share in } 1999\end{array}$ & $31 \%$ & $44 \%$ & $24 \%$ \\
\hline
\end{tabular}

Figure 39 shows the extent of the real appreciation due to the shift from tradeables to nontradeables production. After the transition has been completed, the price of nontradeables reverts to its initial value. The scope of this transition is quite large: in 2040, the employment share of the nontradeables sector has risen by 10 percentage points, from $44 \%$ tot $54 \%$.

The effects that these developments on the goods market have on the rest of the economy can be seen from figure 40. Gross wages rise much faster than they did in the benchmark path (compare figure 40 to figure 2). Higher wage inflation due to a tight labor market results in an increased liability for pension funds, as benefits are tied to the level of wages. These higher liabilities cause an increase in pension premiums.

\section{Conclusions}

The scenarios in this paper show the interdependencies between an ageing population and the costs of labor, net wages, (funded) pension premiums and employment in a small, open economy. Ageing leads to a tighter labor market, higher wages and higher costs for the government. Developments on the international financial markets can, in addition to this, put pressure on the rate of return to capital that pension funds can expect. The tight labor market at the peak of population ageing exacerbates the problems for these pension funds because their benefits have historically been tied to the level of wages. The fact that part of the consumption bundle for consumers has to be produced locally adds to the pressure on local wages. An increase in the supply of labor, however, can smooth the costs of ageing over time. Moreover, better tradeability of goods and services can help to fight the effects of ageing has on the economy. Especially an increase in older worker's labor market participation can be a powerful to combat the costs of aging.

The Dutch economy with its mature, defined-benefit pension funds turns out to be vulnerable to the developments on international capital markets and to changes in the expected length of life. Alternative rules of conduct regarding the division of these risks between working and retired members of the funds have substantial effects on the division of welfare across generations. The tolerance for risk is increased markedly if the pension rights of both workers and retirees can be decreased to repair a shortage in the coverage ratio, thus sharing the risks across a larger number of generations. Also, the relative incomes of cohorts (and their income de- 
velopment) are more balanced if risks are shared in this way, compared to a situation in which only the premium-instrument is used. The indexation-instrument affects employment much less, leaving the economic base to pay for an ageing population intact. This helps to make the Dutch economy more robust to the risks of ageing.

\section{A Model expressions}

\section{A.1 Household optimization}

Households derive utility from the consumption of tradable goods, health care, and leisure over their remaining life. Households are distinguished by their year of birth (generation) $t_{0}$, and by their productivity type $i$. Productivity is exogenous to households but may vary with age. The relative productivity of a household of type $i$ at age $\tau$ is $h(\tau, i)$ and its wage rate is given by $h(\tau, i) p_{l}(t)$ as a consequence of perfect substitution between types in the production of tradables.

We operationalize by specifying seven household types, whose wage profile can be found in figure 41. The share of these seven types in the population varies; we allow for a finer grid towards the higher earners to reflect the large variability in this segment. Shares can be read from table 5 .

Table 5: Type shares and pension sizes

\begin{tabular}{|c|c|c|c|c|c|c|c|c|}
\hline type & 1 & 2 & 3 & 4 & 5 & 6 & 7 & average \\
\hline & \multicolumn{7}{|c|}{ Share in population } & \\
\hline & $12 \%$ & $24 \%$ & $4 \%$ & $24 \%$ & $12 \%$ & $3 \%$ & $2 \%$ & \\
\hline & \multicolumn{8}{|c|}{ Ratio funded occupational pension to public pension } \\
\hline & $0 \%$ & $14 \%$ & $1 \%$ & $65 \%$ & $214 \%$ & $48 \%$ & $33 \%$ & $69.4 \%$ \\
\hline
\end{tabular}

Note: Of these seven productivity types, number 1 is the least productive and number 7 the most productive. The second statistic, the ratio of supplementary pension income over public pension income, is an average over pension-aged type members.

Denote the survival function of a household of generation $t_{0}$ at time $t$ by $\Lambda\left(t, t_{0}\right) \leq 1$. Households maximize their expected utility, given by

$$
\mathrm{E}\left(U\left(t, t_{0}, i\right) \mid t\right)=(1-1 / \gamma)^{-1} \sum_{\tau=t}^{t_{0}+n_{T}-1}(1+\beta)^{t-\tau} \frac{\Lambda\left(\tau-t_{0}+1, t_{0}\right)}{\Lambda\left(t-t_{0}+1, t_{0}\right)} u\left(\tau, t_{0}, i\right)^{1-1 / \gamma}
$$

where $\gamma$ denotes the intertemporal substitution elasticity and $\beta$ the rate of time preference. The 
flow of utility, $u$, is specified as

$$
\begin{aligned}
u\left(t, t_{0}, i\right)= & {\left[\theta_{u}^{1 / \sigma_{u}} c\left(t, t_{0}, i\right)^{\left(\sigma_{u}-1\right) / \sigma_{u}}+\left(1-\theta_{u}\right)^{1 / \sigma_{u}} c_{v}\left(t, t_{0}, i\right)^{\left(\sigma_{u}-1\right) / \sigma_{u}}\right]^{\sigma_{u} /\left(\sigma_{u}-1\right)} } \\
c_{v}\left(t, t_{0}, i\right)= & {\left[\theta_{c v}^{1 / \sigma_{v}}\left(\theta_{v}\left(t, t_{0}, i\right) v\left(t, t_{0}, i\right)\right)^{\left(\sigma_{v}-1\right) / \sigma_{v}}\right.} \\
& \left.+\left(1-\theta_{c v}\right)^{1 / \sigma_{v}}\left(\theta_{z}\left(t, t_{0}, i\right) c_{z}\left(t, t_{0}, i\right)\right)^{\left(\sigma_{v}-1\right) / \sigma_{v}}\right]^{\sigma_{v} /\left(\sigma_{v}-1\right)}
\end{aligned}
$$

where $c$ denotes consumption of tradables, $v$ denotes leisure, and $c_{z}$ denotes consumption of health care. Preference coefficients $\theta$ depend on (i) the state of knowledge, reflected in the labour productivity growth rate $\alpha$, (ii) the productivity type $i$, to represent the idea that human capital does not affect the labour-leisure choice, and (iii) age $t-t_{0}+1$ :

$$
\begin{aligned}
\theta_{v}\left(t, t_{0}, i\right) & =\theta_{0} h\left(t-t_{0}+1, i\right)^{\eta_{h}}(1+\alpha)^{t_{0}}(1+\theta)^{t_{0}-t} \quad\left(\eta_{h}>0\right) \\
\theta_{z}\left(t, t_{0}, i\right) & =\theta_{1} h\left(t-t_{0}+1, i\right)^{\eta_{h}}(1+\alpha)^{t_{0}} \theta_{t}\left(t-t_{0}+1, t_{0}\right) \\
\theta_{t}\left(t-t_{0}+1, t_{0}\right) & =\theta_{t}\left(t-t_{0}, t_{0}\right)\left((1+\theta)^{\eta_{1}} \frac{\eta_{2} \lambda\left(\tau-t_{0}, t_{0}\right)+\eta_{3}}{\eta_{2} \lambda\left(\tau+1-t_{0}, t_{0}\right)+\eta_{3}}\right)^{1 /\left(1-\sigma_{v}\right)}
\end{aligned}
$$

where $h^{\eta_{h}}$ represents the effect of productivity, $\theta$ and $\theta_{t}$ is the effect of age on leisure and health care, respectively. The effect of age on the demand for health care is linked to the mortality rate, $\lambda\left(\tau, t_{0}\right)=1-\Lambda\left(\tau+1, t_{0}\right) / \Lambda\left(\tau, t_{0}\right)$. Households can divide their time between leisure $v$, labour $l$, and health care $c_{z}$

$$
l=l_{\max }-v-c_{z} \geq 0
$$

An important consequence of this formulation is that health care takes time that cannot be used for leisure or labour.

Maximization of expected utility is a complicated problem, due to the restriction on total time (1) above. We derive expressions for the supply of labor and the demand for tradeables and health care in terms of shadow prices, which themselves follow from numerical computations. A detailed treatment of the solution can be found in the model's documentation, available on the internet: http://image.ocfeb.nl.

\section{A.2 Firm optimization}

Firms in the tradable goods sector use capital $K$, labour $L$, and raw materials $M$ to produce output. Production is subject to (internal) adjustment costs in capital formation. Technical change is purely labour augmenting, at rate $\alpha$. Labour and raw materials are variable inputs. Labour productivity is heterogeneous by age and skill type, but workers of all types are perfectly substitutable. As above, let the productivity of a worker of age $\tau$ and of type $i$ be equal to $h(\tau, i)$, 
then the production function reads as follows

$$
\begin{aligned}
y(t) & =\mathrm{F}[M(t), H(t)]-\frac{1}{2} c_{I} \frac{I^{2}(t)}{K(t)} \\
F[M, H] & =\left[\zeta_{M} M^{-\rho_{y}}+\zeta_{H} H^{-\rho_{y}}\right]^{-1 / \rho_{y}} \\
H(t) & =\left[\zeta_{K} K(t)^{-\rho_{H}}+\zeta_{L}\left(L_{\text {eff }}(t)(1+\alpha)^{t}\right)^{-\rho_{H}}\right]^{-1 / \rho_{H}} \\
L_{\text {eff }}(t) & =\sum_{\tau=t-n_{T}+1}^{t} \sum_{i=1}^{n_{I}} h(t-\tau+1, i) L(t, \tau, i)
\end{aligned}
$$

Here gross output $F$ is a CES-function of raw materials $M$ and value added $H$, with substitution elasticity $\sigma_{y}=1 /\left(1+\rho_{y}\right)$ (see table 1$)$. Value added $H$ is produced by using beginning-ofperiod capital stock $K$ and labour input in efficiency units $L_{\text {eff }}$ (with substitution elasticity $\left.\sigma_{H}=1 /\left(1+\rho_{H}\right)\right)$. The latter is defined as the sum of the efficiency units supplied by the $n_{T}$ age classes and the $n_{I}$ productivity types. Internal adjustment costs are subtracted in the definition of net output $y$, where $I$ denotes composite investment.

Firms maximize the present value of the stream of future dividends. Due to the rigidity in the capital stock, the marginal value of labor in this production process varies over time. With perfect labor markets, this variation leads to the path of gross wages that we use in this paper, see for instance figure 2. Once again, mathematical optimization leads to a solution which is detailed in the model's documentation.

\section{References}

Aglietta, M., Arezki, R., Breton, R., Fayolle, J., Juillard, M., Lacu, C., Cacheux, J. L., Rzepkowski, B. and Touzé, V.: 2001, INGENUE, a multi-regional computable general equilibrium, overlapping-generations model, INGENUE Team. Mimeo, CEPII, CEPREMAP,MINIUniversity of Paris X and OFCE. Internet: http://ideas.repec.org/p/sce/scecf0/178.html.

Auerbach, A. and Kotlikoff, L. J.: 1987, Dynamic Fiscal Policy, Cambridge University Press.

Beetsma, R., Bettendorf, L. and Broer, P.: 2003, The budgetary and economic consequences of ageing in the Netherlands, Economic Modelling.

Börsch-Supan, A., Ludwig, A. and Winter, J.: 2003, Aging, pension reform, and capital flows, a multi-country simulation model, mimeo, Institut für Volkswirtschaftslehre und Statistik, Universität Mannheim.

Broer, D. P.: 1999, Growth and welfare distribution in an ageing society: An applied general equilibrium analysis for the netherlands, Ocfeb Research Memorandum \# 9908, Erasmus University Rotterdam. Internet: http://www.few.eur.nl/few/research/pubs/ocfeb/documents/ rm9908.pdf.

CBS/CPB: 1997, Bevolking en arbeidsaanbod: drie scenarios tot 2020, Sdu Uitgevers, Den Haag. 
CPB: 2003a, JADE, a model for the Joint Analysis of Dynamics and Equilibrium, Document \# 30. Internet: http://www.cpb.nl/nl/pub/document/30.

CPB: 2003b, Vergrijzing en schuldreductie - een indicatieve update, Notitie. Internet: http: //www.cpb.nl/nl/pub/notitie/13feb2003/.

Kotlikoff, L. J., Smetters, K. and Walliser, J.: 2001, Finding a way out of America's demographic dilemma, NBER Working Paper \# 8258, Cambridge MA. Internet: http://www.nber. org/papers/w8258.

Yaari, M.: 1965, Uncertain lifetime, life insurance and the theory of the consumer, Review of Economic Studies 32, 137-150. 


\section{A Figures}

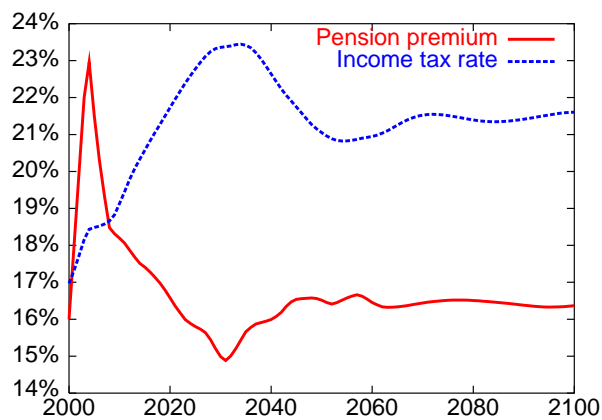

Figure 1: Income tax rate and pension premium rate on the base path, with premium instrument.

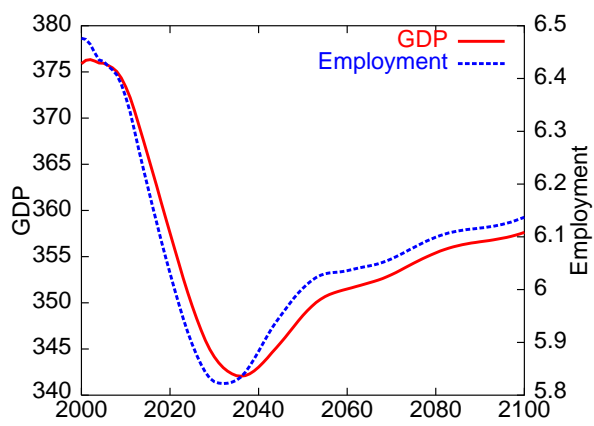

Figure 3: Employments in millions of fte's (right) and GDP in billions of Euros (left, corrected for technological growth) on the base path.

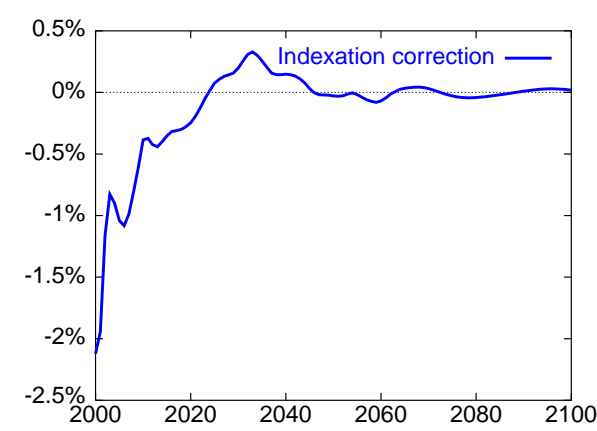

Figure 5: Indexation correction, expressed as missed yearly increase in pensions.

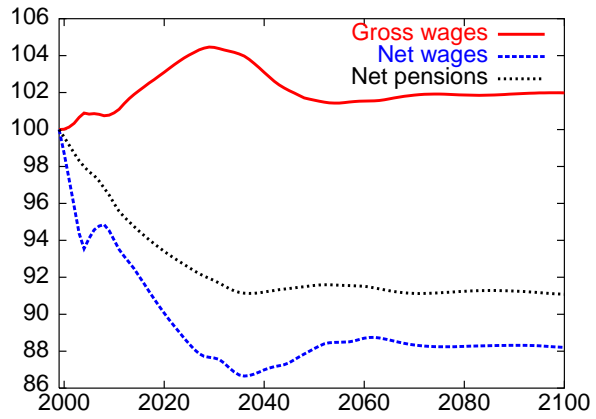

Figure 2: Gross wage, net wage and net pensions in index numbers (corrected for technological growth) on the base path.

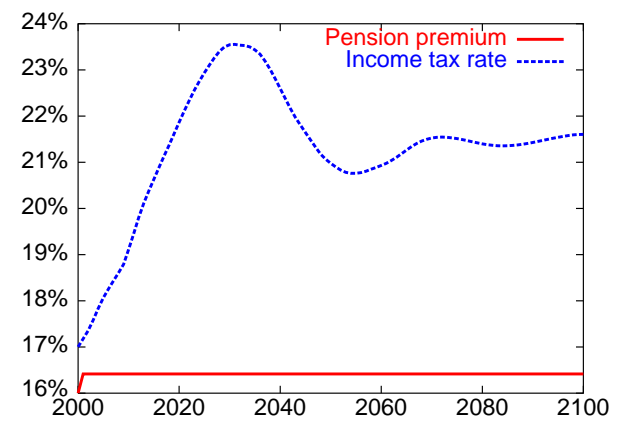

Figure 4: Income tax rate and pension premium rate, with indexation instrument.

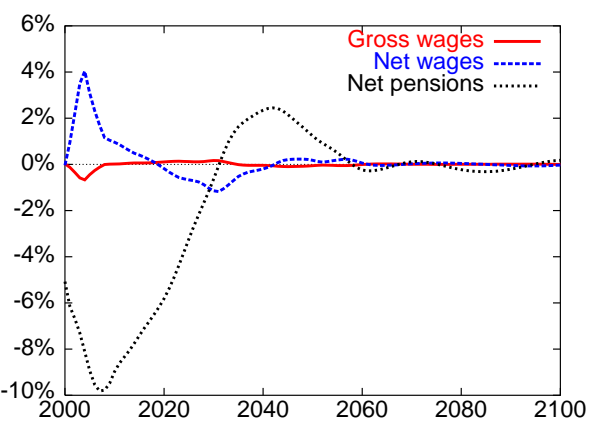

Figure 6: Changes in gross wage, net wage and net pensions relative to the base path, with indexation instrument. 


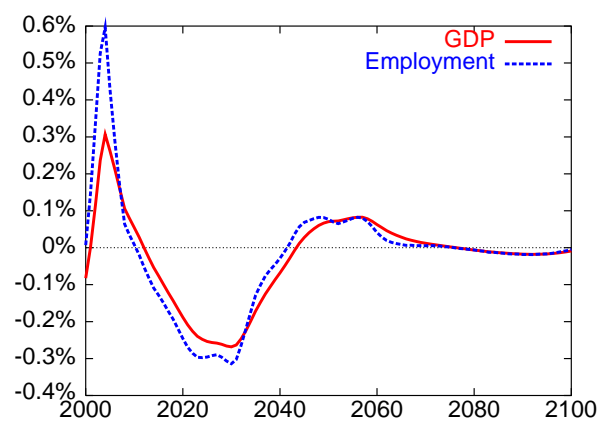

Figure 7: GDP and employment with indexation instrument relative to the base path.

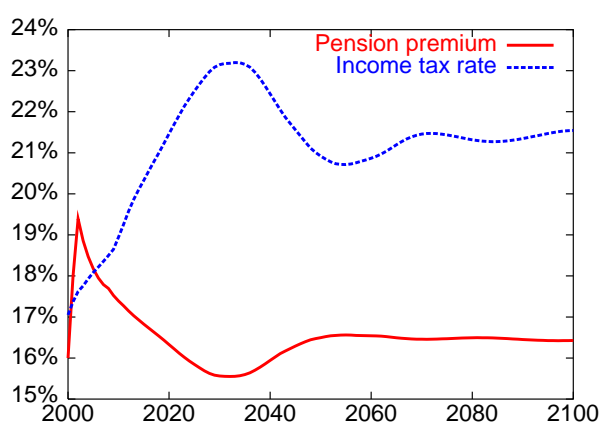

Figure 9: Income tax rate and pension premium after switch to average wage, with premium instrument.

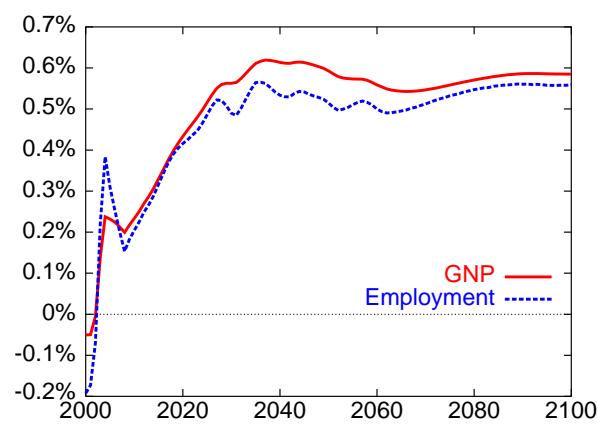

Figure 11: GDP and employment relative to the base path after switch to average wage system, with premium instrument.

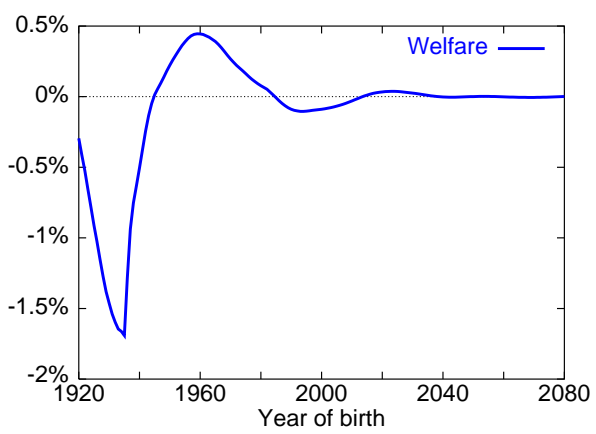

Figure 8: Welfare effects of the use by pension funds of the indexation instrument instead of the premium instrument.

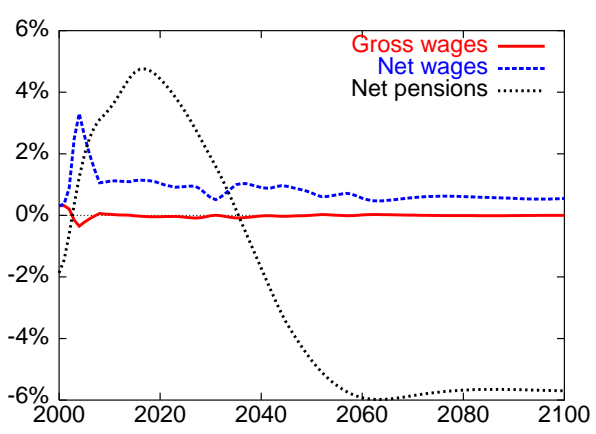

Figure 10: Gross wage, net wage and net pensions relative to the base path after switch to average wage system, with premium instrument.

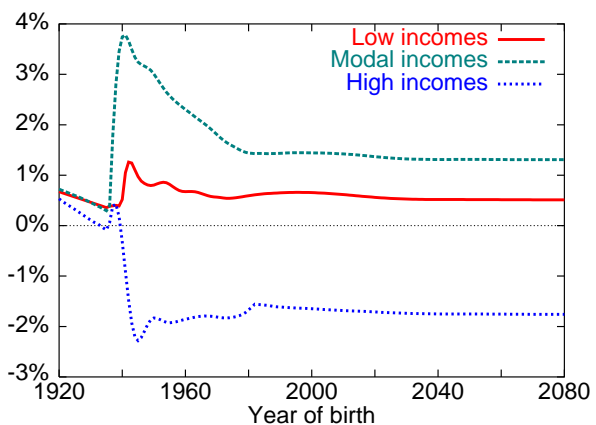

Figure 12: Welfare effects of a switch to average wage system, with premium instrument. 


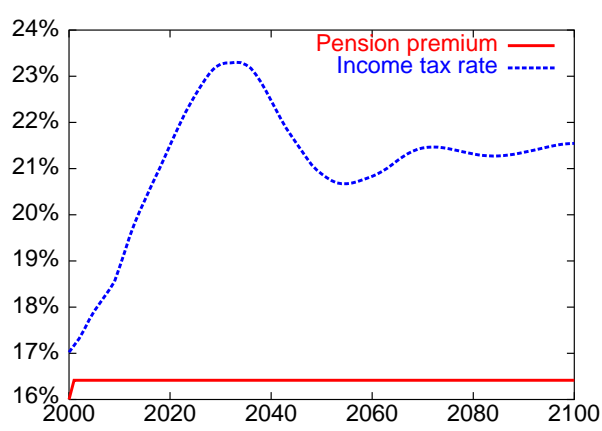

Figure 13: Income tax rate and pension premium after switch to average wage system, with premium instrument.

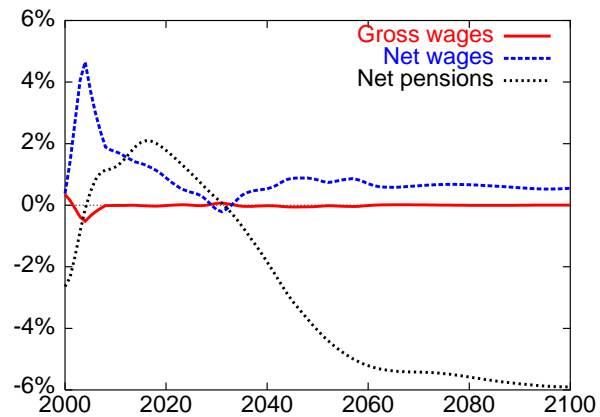

Figure 15: Gross wage, net wage and net pensions relative to the base path after switch to average wage system, with indexation instrument.

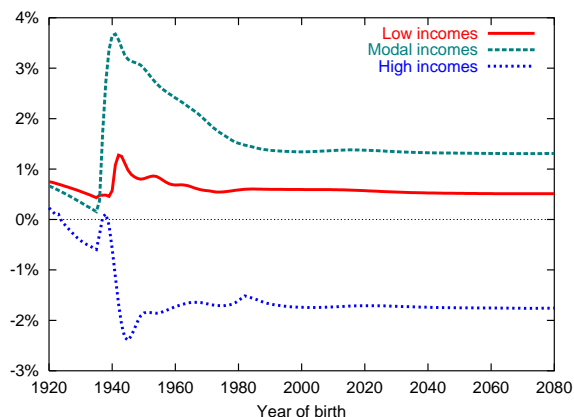

Figure 17: Welfare effects of a switch to average wage system, with indexation instrument.

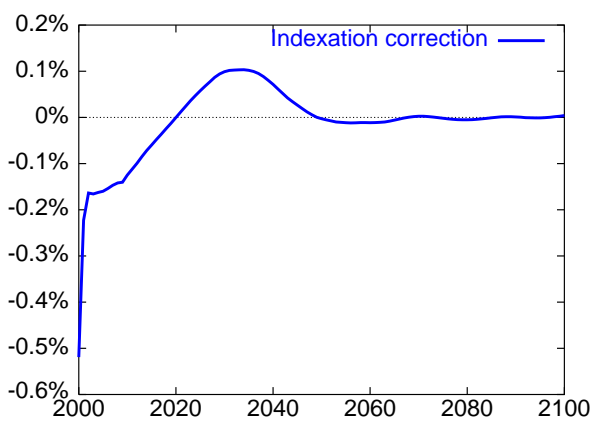

Figure 14: Indexation correction, expressed as missed yearly increase in pensions, under average wage system (with indexation instrument).

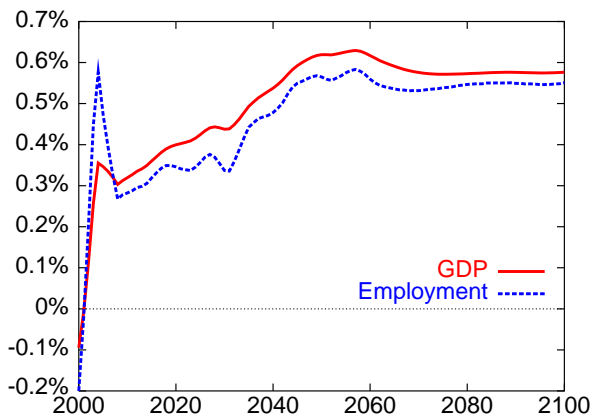

Figure 16: GDP and employment relative to the base path after switch to average wage system, with indexation instrument.

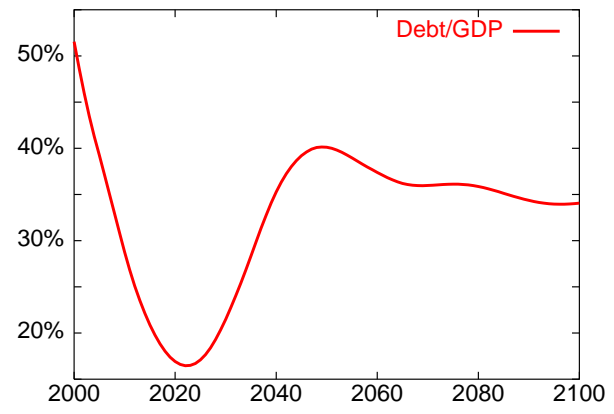

Figure 18: Government debt as a fraction of GDP, with tax smoothing 


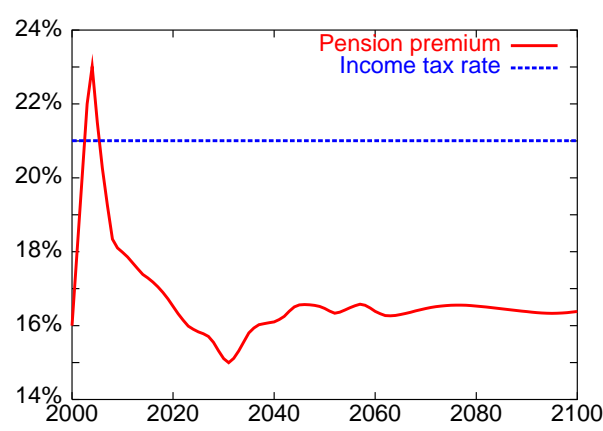

Figure 19: Income tax rate en pension premium with tax smoothing

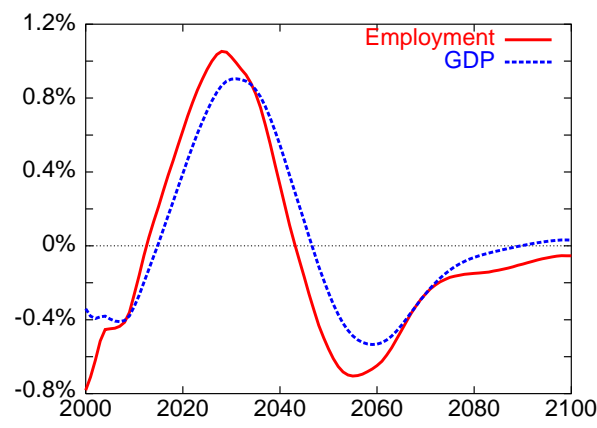

Figure 21: GDP and employment relative to the base path with tax smoothing

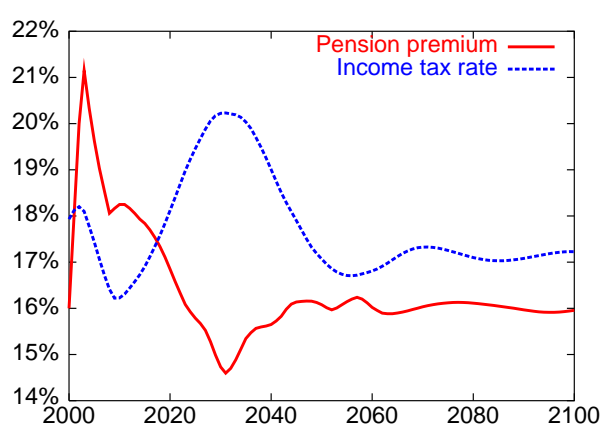

Figure 23: Income tax rate en pension premium with increasing participation.

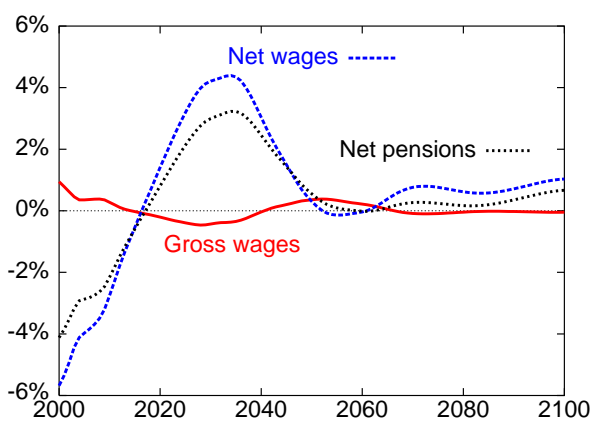

Figure 20: Gross wage, net wage and net pensions relative to the base path with tax smoothing

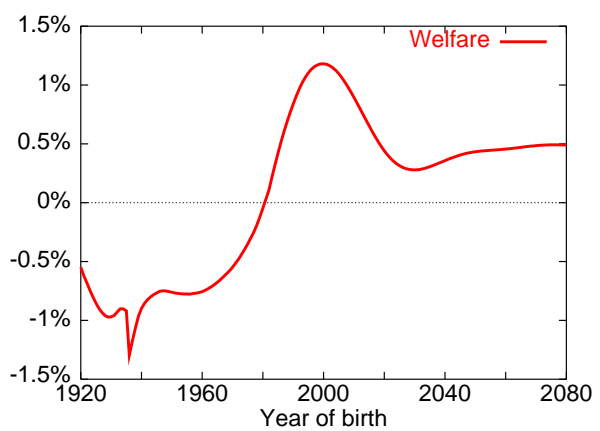

Figure 22: Welfare effects of tax smoothing.

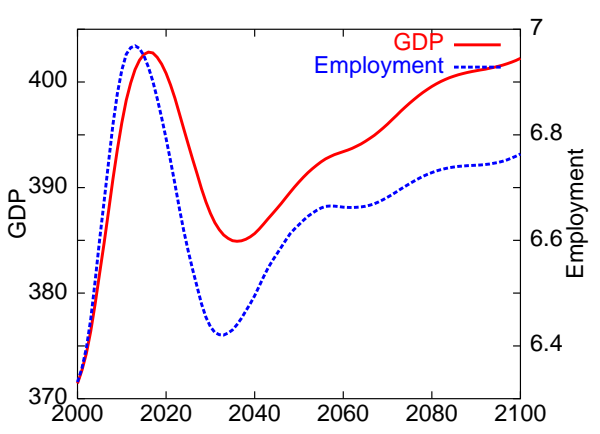

Figure 24: GDP (left, billions of euro's) and employment (right, millions of fte's) with increasing participation. 


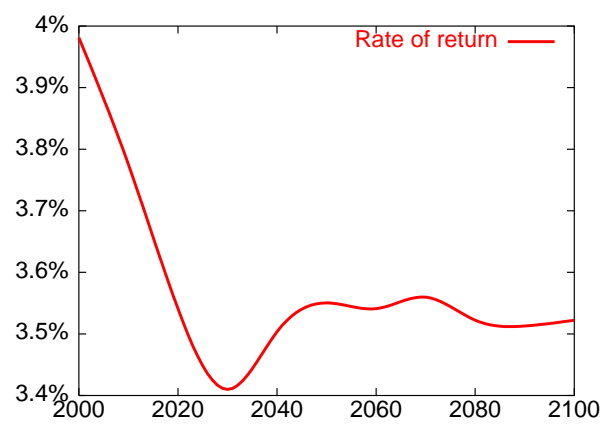

Figure 25: Projection of the rate of return to capital accoriding to the INGENUE model.

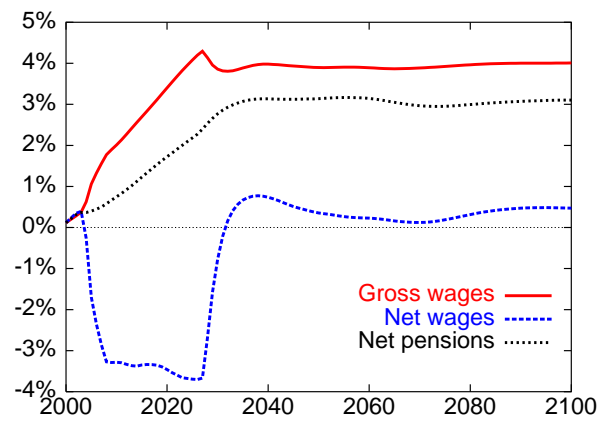

Figure 27: Gross wage, net wage and net pensions relative to the base path after interest shock, with premium instrument.

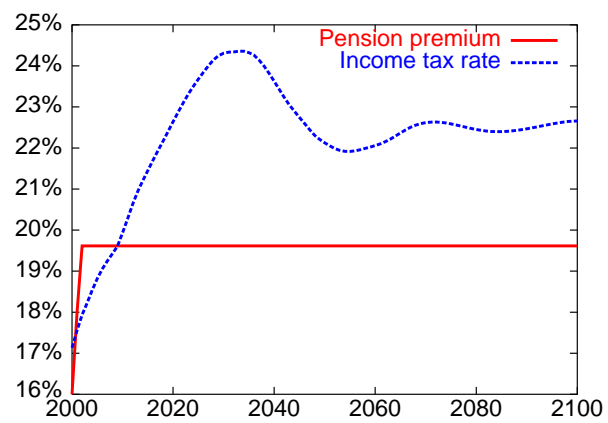

Figure 29: Income tax rate en pension premium after interest shock with indexation instrument.

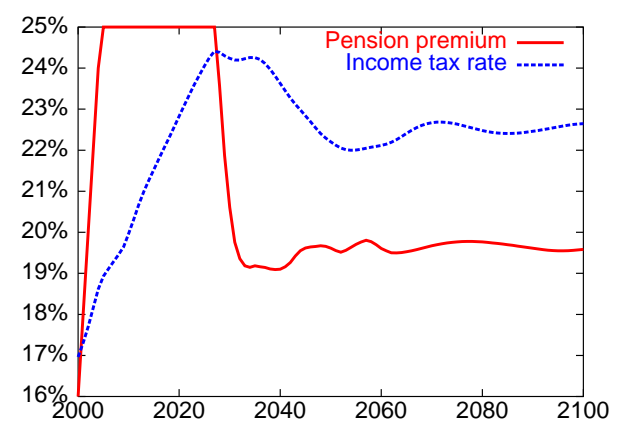

Figure 26: Income tax rate en pension premium after interest shock, with premium instrument.

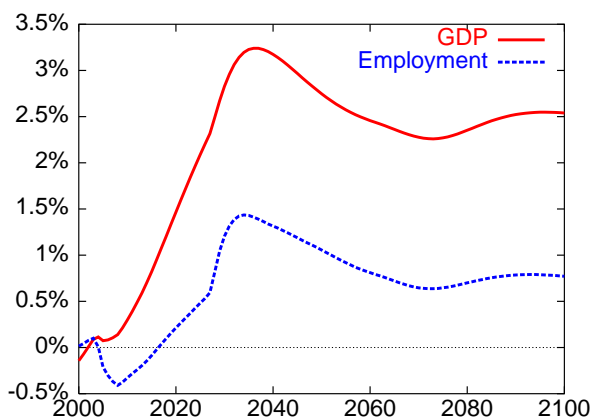

Figure 28: GDP and employment relative to the base path after interest shock, with premium instrument.

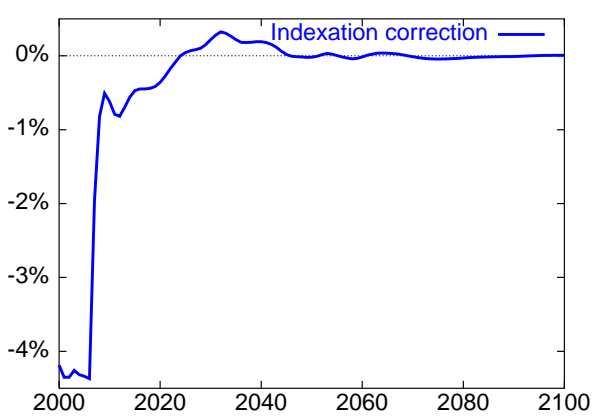

Figure 30: Indexation reduction, expressed in missed yearly increase in pensions, under endwage system after interest shock (with indexation instrument). 


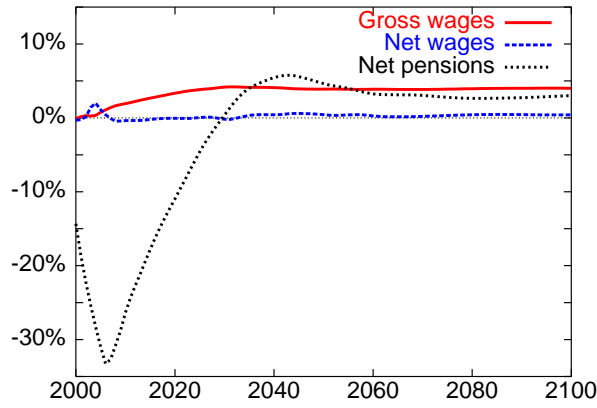

Figure 31: Gross wage, net wage and net pensions relative to the base path after interest shock, with indexation instrument.

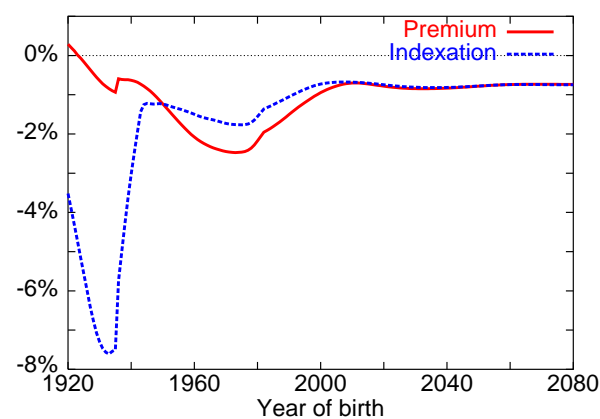

Figure 33: Welfare effects interest shock with premium - and indexation instrument.

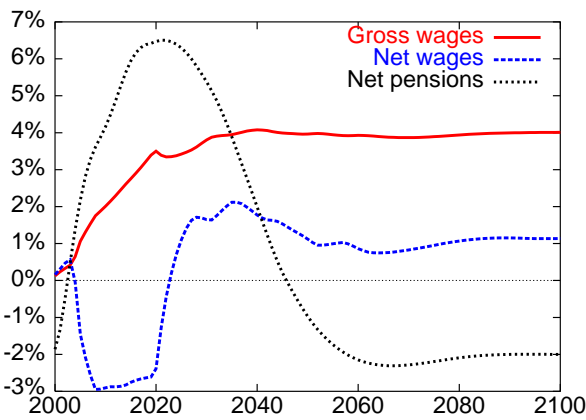

Figure 35: Gross wage, net wage and net pensions relative to the base path after interest shock, with average wage system and premium instrument.

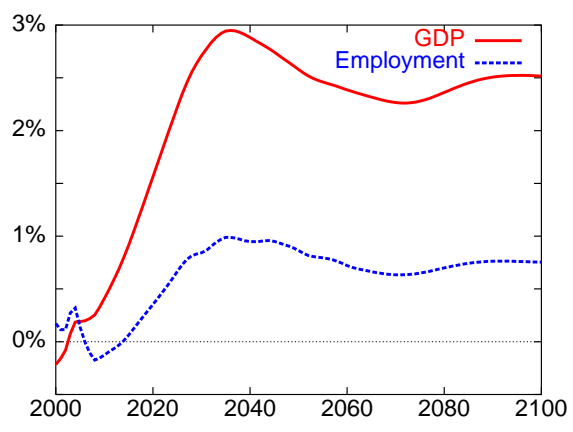

Figure 32: GDP and employment relative to the base path after interest shock, with indexation instrument

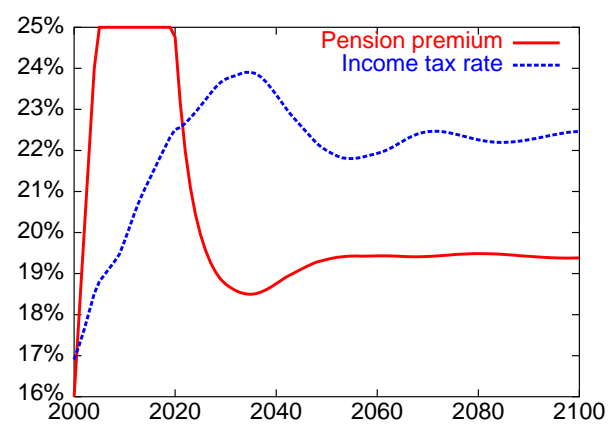

Figure 34: Income tax rate en pension premium after interest shock, with average wage system and premium instrument.

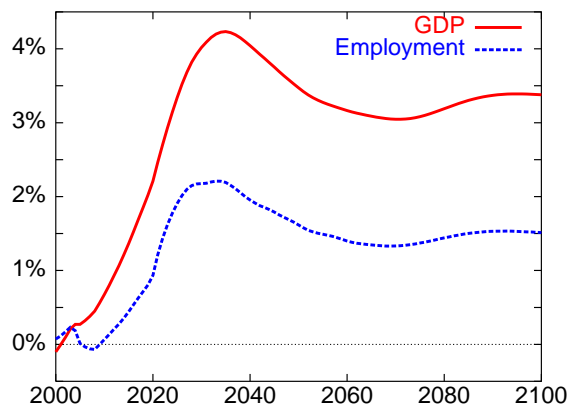

Figure 36: GDP and employment relative to the base path after interest shock, with average wage system, premium instrument. 


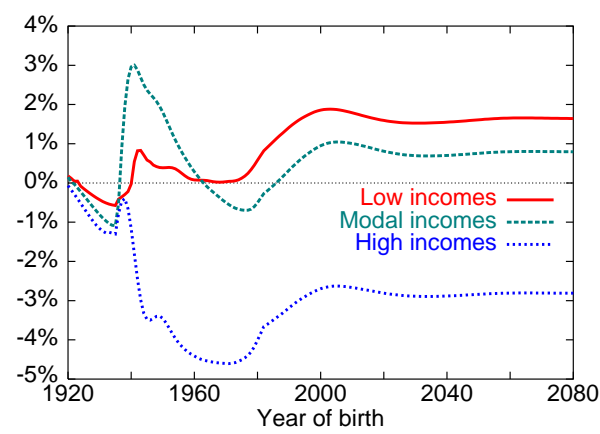

Figure 37: Welfare effects of interest rate shock with average wage system and premium instrument.

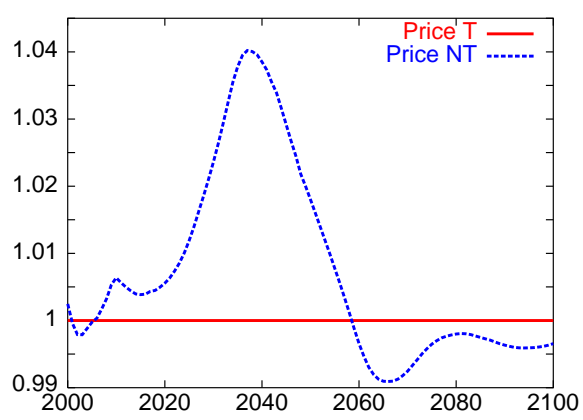

Figure 39: The price of tradeable (V) and non-tradeable goods (NV).

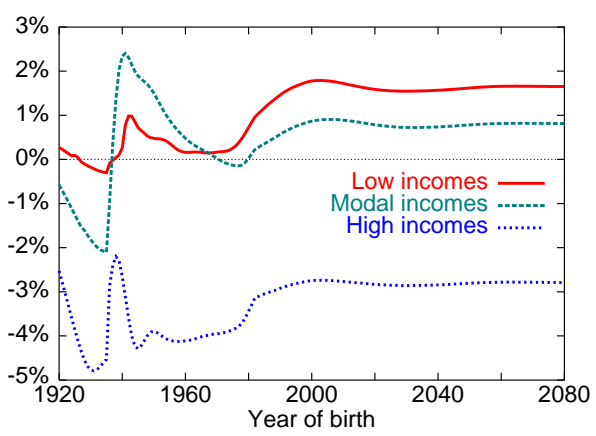

Figure 38: Welfare effects of interest rate shock with average wage system and indexation instrument.

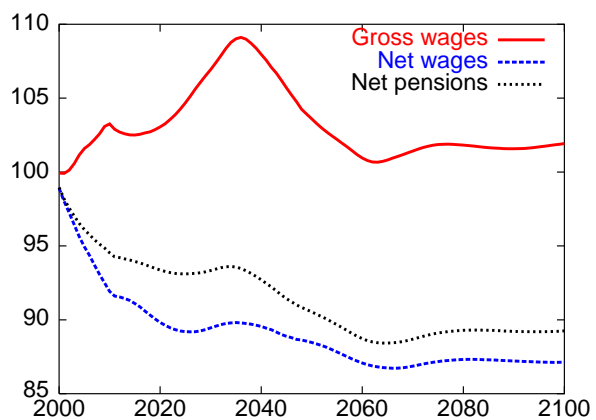

Figure 40: Gross wage, net wage and net pensions in a scenario with non-tradeable goods.

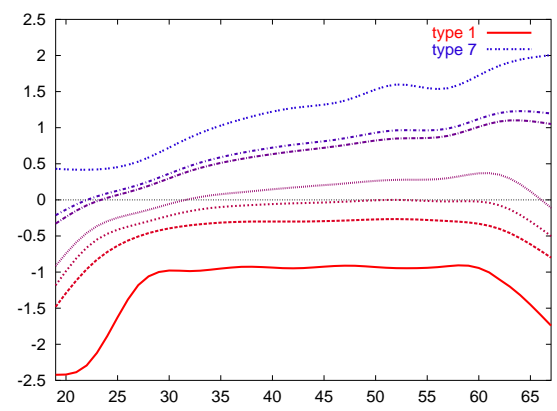

Figure 41: Wage profiles (logs) for different productivity types as a function of age. 


\title{
CESifo Working Paper Series
}

\author{
(for full list see www.cesifo.de)
}

1342 Johannes Becker and Clemens Fuest, A Backward Looking Measure of the Effective Marginal Tax Burden on Investment, November 2004

1343 Heikki Kauppi, Erkki Koskela and Rune Stenbacka, Equilibrium Unemployment and Capital Intensity Under Product and Labor Market Imperfections, November 2004

1344 Helge Berger and Till Müller, How Should Large and Small Countries Be Represented in a Currency Union?, November 2004

1345 Bruno Jullien, Two-Sided Markets and Electronic Intermediaries, November 2004

1346 Wolfgang Eggert and Martin Kolmar, Contests with Size Effects, December 2004

1347 Stefan Napel and Mika Widgrén, The Inter-Institutional Distribution of Power in EU Codecision, December 2004

1348 Yin-Wong Cheung and Ulf G. Erlandsson, Exchange Rates and Markov Switching Dynamics, December 2004

1349 Hartmut Egger and Peter Egger, Outsourcing and Trade in a Spatial World, December 2004

1350 Paul Belleflamme and Pierre M. Picard, Piracy and Competition, December 2004

1351 Jon Strand, Public-Good Valuation and Intrafamily Allocation, December 2004

1352 Michael Berlemann, Marcus Dittrich and Gunther Markwardt, The Value of NonBinding Announcements in Public Goods Experiments: Some Theory and Experimental Evidence, December 2004

1353 Camille Cornand and Frank Heinemann, Optimal Degree of Public Information Dissemination, December 2004

1354 Matteo Governatori and Sylvester Eijffinger, Fiscal and Monetary Interaction: The Role of Asymmetries of the Stability and Growth Pact in EMU, December 2004

1355 Fred Ramb and Alfons J. Weichenrieder, Taxes and the Financial Structure of German Inward FDI, December 2004

1356 José Luis Moraga-González and Jean-Marie Viaene, Dumping in Developing and Transition Economies, December 2004

1357 Peter Friedrich, Anita Kaltschütz and Chang Woon Nam, Significance and Determination of Fees for Municipal Finance, December 2004 
1358 M. Hashem Pesaran and Paolo Zaffaroni, Model Averaging and Value-at-Risk Based Evaluation of Large Multi Asset Volatility Models for Risk Management, December 2004

1359 Fwu-Ranq Chang, Optimal Growth and Impatience: A Phase Diagram Analysis, December 2004

1360 Elise S. Brezis and François Crouzet, The Role of Higher Education Institutions: Recruitment of Elites and Economic Growth, December 2004

1361 B. Gabriela Mundaca and Jon Strand, A Risk Allocation Approach to Optimal Exchange Rate Policy, December 2004

1362 Christa Hainz, Quality of Institutions, Credit Markets and Bankruptcy, December 2004

1363 Jerome L. Stein, Optimal Debt and Equilibrium Exchange Rates in a Stochastic Environment: an Overview, December 2004

1364 Frank Heinemann, Rosemarie Nagel and Peter Ockenfels, Measuring Strategic Uncertainty in Coordination Games, December 2004

1365 José Luis Moraga-González and Jean-Marie Viaene, Anti-Dumping, Intra-Industry Trade and Quality Reversals, December 2004

1366 Harry Grubert, Tax Credits, Source Rules, Trade and Electronic Commerce: Behavioral Margins and the Design of International Tax Systems, December 2004

1367 Hans-Werner Sinn, EU Enlargement, Migration and the New Constitution, December 2004

1368 Josef Falkinger, Noncooperative Support of Public Norm Enforcement in Large Societies, December 2004

1369 Panu Poutvaara, Public Education in an Integrated Europe: Studying to Migrate and Teaching to Stay?, December 2004

1370 András Simonovits, Designing Benefit Rules for Flexible Retirement with or without Redistribution, December 2004

1371 Antonis Adam, Macroeconomic Effects of Social Security Privatization in a Small Unionized Economy, December 2004

1372 Andrew Hughes Hallett, Post-Thatcher Fiscal Strategies in the U.K.: An Interpretation, December 2004

1373 Hendrik Hakenes and Martin Peitz, Umbrella Branding and the Provision of Quality, December 2004 
1374 Sascha O. Becker, Karolina Ekholm, Robert Jäckle and Marc-Andreas Mündler, Location Choice and Employment Decisions: A Comparison of German and Swedish Multinationals, January 2005

1375 Christian Gollier, The Consumption-Based Determinants of the Term Structure of Discount Rates, January 2005

1376 Giovanni Di Bartolomeo, Jacob Engwerda, Joseph Plasmans, Bas van Aarle and Tomasz Michalak, Macroeconomic Stabilization Policies in the EMU: Spillovers, Asymmetries, and Institutions, January 2005

1377 Luis H. R. Alvarez and Erkki Koskela, Progressive Taxation and Irreversible Investment under Uncertainty, January 2005

1378 Theodore C. Bergstrom and John L. Hartman, Demographics and the Political Sustainability of Pay-as-you-go Social Security, January 2005

1379 Bruno S. Frey and Margit Osterloh, Yes, Managers Should Be Paid Like Bureaucrats, January 2005

1380 Oliver Hülsewig, Eric Mayer and Timo Wollmershäuser, Bank Loan Supply and Monetary Policy Transmission in Germany: An Assessment Based on Matching Impulse Responses, January 2005

1381 Alessandro Balestrino and Umberto Galmarini, On the Redistributive Properties of Presumptive Taxation, January 2005

1382 Christian Gollier, Optimal Illusions and Decisions under Risk, January 2005

1383 Daniel Mejía and Marc St-Pierre, Unequal Opportunities and Human Capital Formation, January 2005

1384 Luis H. R. Alvarez and Erkki Koskela, Optimal Harvesting under Resource Stock and Price Uncertainty, January 2005

1385 Ruslan Lukach, Peter M. Kort and Joseph Plasmans, Optimal R\&D Investment Strategies with Quantity Competition under the Threat of Superior Entry, January 2005

1386 Alfred Greiner, Uwe Koeller and Willi Semmler, Testing Sustainability of German Fiscal Policy. Evidence for the Period 1960 - 2003, January 2005

1387 Gebhard Kirchgässner and Tobias Schulz, Expected Closeness or Mobilisation: Why Do Voters Go to the Polls? Empirical Results for Switzerland, 1981 - 1999, January 2005

1388 Emanuele Bacchiocchi and Alessandro Missale, Managing Debt Stability, January 2005

1389 Assar Lindbeck and Dirk Niepelt, Improving the SGP: Taxes and Delegation rather than Fines, January 2005 
1390 James J. Heckman and Dimitriy V. Masterov, Skill Policies for Scotland, January 2005

1391 Emma Galli \& Fabio Padovano, Sustainability and Determinants of Italian Public Deficits before and after Maastricht, January 2005

1392 Angel de la Fuente and Juan Francisco Jimeno, The Private and Fiscal Returns to Schooling and the Effect of Public Policies on Private Incentives to Invest in Education: A General Framework and Some Results for the EU, January 2005

1393 Juan C. Conesa and Carlos Garriga, Optimal Response to a Demographic Shock, January 2005

1394 Christian Gollier, Optimal Portfolio Management for Individual Pension Plans, February 2005

1395 Ruslan Lukach, Joseph Plasmans and Peter M. Kort, Innovation Strategies in a Competitive Dynamic Setting, February 2005

1396 Gebhard Kirchgässner, (Why) Are Economists Different?, February 2005

1397 Marko Köthenbürger, Panu Poutvaara and Paola Profeta, Why are More Redistributive Social Security Systems Smaller? A Median Voter Approach, February 2005

1398 Gabrielle Demange, Free Choice of Unfunded Systems: A First Assessment, February 2005

1399 Carlos Fonseca Marinheiro, Sustainability of Portuguese Fiscal Policy in Historical Perspective, February 2005

1400 Roel M. W. J. Beetsma and Koen Vermeylen, The Effect of Monetary Unification on Public Debt and its Real Return, February 2005

1401 Frank Asche, Petter Osmundsen and Maria Sandsmark, Is It All Oil?, February 2005

1402 Giacomo Corneo, Media Capture in a Democracy: The Role of Wealth Concentration, February 2005

1403 A. Lans Bovenberg and Thijs Knaap, Ageing, Funded Pensions and the Dutch Economy, February 2005 